DOI 10.31558/1815-3070.2019.37.2

УДК 811.161. 2'373. 6-112

\title{
ІСТОРІЯ СЛОВА СТІЛ ЯК РЕПРЕЗЕНТАЦІЯ СПІЛЬНОСЛОВ’ЯНСЬКОЇ НАЗВИ МЕБЛІВ
}

У статті досліджено історію появи та поширення в украӥнській мові лексеми стіл як назви хатніх меблів. Розглянуто особливості функиіювання слова в украӥнській мові від давньокиївського періоду до сучасного етапу та відображення в інших слов'янських мовах, украӥнських діалектах. Описано похідні утворення від нього та назви елементів столу як свідчення затребуваності та значного поширення лексеми стіл, ї̈ дериватів та демінутивів.

Ключові слова: історична діалектологія украӥнської мови, історична лексикологія та словотвір української мови, лексичне значення, полісемічність, демінутив.

\section{Постановка проблеми у загальному вигляді та їі зв'язок із важливими науковими чи практичними завданнями \\ Однією з актуальних проблем історії мови до цього часу є дослідження словникового складу української} мови через історико-лінгвістичний аспект. На сучасному етапі визріла потреба у глибокому різноаспектному дослідженні лексичного складу мови, пов'язаного з побутом. Особливий інтерес для дослідників може становити саме побутова лексика, яка до цього часу є однією з груп тематичної лексики, що недостатньо досліджені в історичному та мовознавчому аспектах. У сучасній лінгвістиці широко досліджуються конкретні лексико-семантичні та тематичні групи слів.

Аналіз останніх досліджень і публікацій, в яких започатковано розв'язання даної проблеми і на які спирається автор. Питання дослідження історії слів, їх лексико-семантичних груп привертало увагу великої кількості лінгвістів. Автори багатьох наукових розвідок досліджували різні групи лексики: А. Бурячок (Burachok) (назви спорідненості і свояцтва в українській мові), В. Горобець (Horobets) (лексика історично-мемуарної прози першої половини XVIII ст.), О. Муромцева (Muromtseva) (лексичний склад літературної мови другої половини XIX - початку XX ст.), Г. Наєнко (Najenko) (астрономічна термінологія староукраїнських пам'яток), О. Прискока (Pryskoka) (архітектурна лексика давніх українських писемних пам'яток). В останні десятиліття активізувався процес вивчення стародавніх текстів, праць староукраїнських лексикографів, матеріалів, зібраних у картотеці «Словника української мови XVI - першої половини XVII ст.».

Актуальність дослідження.

Актуальність дослідження обумовлена важливістю вивчення лексики, яка є безпосереднім відображенням побуту, історії, духовної та матеріальної культури народу. Побутова лексика - активний шар словникового запасу, для якого характерні динамічність та різноманітні семантичні процеси. Це дає змогу глибше дослідити семантичні та дериваційні зміни в структурі слів цієї тематичної групи та лексико-семантичних груп усередині неї. Тема дослідження $є$ актуальною, бо побутова лексика на позначення назв меблів не ставала до цього часу предметом детального вивчення. До сьогодні не було зроблено спроби щодо системного дослідження тематичної групи слів ‘назви меблів’ та лексико-семантичної групи назв стола та його частин як окремого виду меблів.

Мета - розглянути та проаналізувати лексеми упродовж їх функціювання в українській мові, які входять до лексико-семантичної групи назв стола та його частин, упродовж їх функціювання в українській мові (XIIXX ст.).

Лексико-семантична група назв стола та його частин не є чисельною в українській мові. Лексема $\mathrm{cmiл}$ немає загальноприйнятої етимології. Дослідники вказують на можливе праслов'янське коріння. Псл. stolb засвоєне старослов'янською мовою й набуло форми столь, а звідти перейшло до різних слов'янських мов: стол у російській, білоруській, болгарських мовах; stół у польській, stůl у чеській мові (ЕСУМ, V, с. 419). А. Брюкнер (Brückner 517), В. Машек (Machek 590), С. Младенов (Mladenov 610) та інші дослідники припускаються думки про можливе зближення праслов'янського stolъ 3 литовським stãlas зі значенням 'стіл', у множині раstõlai зі значенням 'підмостки' та варіантами цього слова в інших неслов'янських мовах, які утворилися від праслов'янського *stati, *stojo, що були дієсловами зі значенням 'стояти’ (ЕСУМ, V, с. 419). У М. Фасмера (Fasmer 764-765) натрапляємо на схоже потрактування української лексеми стіл, російською стол, окрім того, він наводить думки вчених, які роблять припущення про чергування голосних steljo / stblati та порівнюють його 3 дн-інд. sthálam, що в перекладі означає 'возвышение, холм, материк'. Автор «Этимологического словаря русского языка» наводить думку дослідників про так званий окситонований наголос: у родовому відмінку однини стола вказує на те, що воно є похідним від стелю (Ф., III, с. 764-765).

Давньокиївські пам'ятки засвідчують лексему в непрямих відмінках столь: Никиөоръ митрополить на столь посаженъ (ПВЛ, ЛЛ, с. 280); а посаженъ на столь (ПВЛ, ЛЛ, с. 274); ...поиди княже на столь Фтенъ и дbдденъ (ЛК, с. 275). 3 цього контексту можемо зробити припущення про вплив на давню українську мову церковно-слов'янської. Підтвердженням цієї думки виступає лексичне значення слова столь. Воно вжито у переносному значенні поряд із традиційним потрактування столу як назви виду меблів, за яким приймали їжу. Можливо, воно означало якесь підвищення, стілець, крісло, у якому сиділа особа, яка була уповноважена виконувати управлінські функції (говорячи сучасною мовою). На той час у мові паралельно використовували дві форми - cmoлt і столь. Інших пояснень лексичного значення на українському грунті ми не віднайшли. I. Срез-

(C) Науменко Л., 2019 
невський подає лексеми столь та стольи̧ь, розмежовує при цьому відтінки значень, які були закріплені за кожним словом. Автор чітко визначає лексичне значення столь як 'скамья’: Полагаше на столь. Спаше на столь древянь. Сьдоша на стольхъ. Епископи ...сідають на уготованныхъ имъ стольхъ, каиждо на своемъ мьсть, по своему степени (Срезн., III, с. 516-517), 'столь': На празни(к) по всей и(е)ркви поставля(ют) столы ї на них возлага(ют) мощи с свя)mbl(x) (Срезн., III, с. 516-517); 'аналой’; ‘престолъ, тронъ’; ‘престолъ’ (як символ верховної влади); 'столица', 'могущество', 'епископское сьдалище въ цђркви'; 'каөедра епископская’; 'престолъ (какъ символъ учительной власти)', ‘подножіе’ [Срезн., III, с. 517-518]; ‘повозка' як сумнівне, не чітко визначене трактування: Столь готовъ (Срезн., III, с. 518). І. Срезневський робить припущення про спорідненість давнього столь 3 литовським stalas - столь, пруським - stalis, ірландським sdial-cmoль, sdol-cmуль (Срезн., III, с. 518). Дериват стольникъ, утворений суфіксальним способом (суфікс -икъ), також є полісемічним: 1) занимающий святительський престоль, святитель; 2) предстоятель; 3) домоправитель (лексичне значення не чітко визначене); 4) дворцовая должность и чинъ въ Древней Руси; 5) должность при епископахъ (Срезн., III, с. 518-519). У цьому разі багатозначність вказує не на різні значення слова, а на відтінки значень. Інший прикметник стольний є дериватом від іменника стол - престол. Слово означає назву посади у різних сферах світського та церковного життя. Дериват від стольникъ прикметник стольничии (суфікс -ич) служить для називання всього, що має відношення до посади стольника (Срезн., III, с. 519).

У староукраїнській мові XIV-XV ст. вживалися граматичні варіанти столь та столєuъ, а у словниках цього періоду зафіксовано розширення їх семантики. Графічне відтворення та лексичне значення слова столь не змінюється, воно лише деталізується й означає назву престолу як єпископської кафедри: мы Олєксандро воєвода ... знаємо чинимъ... оже тотъистинныли Оганєсъ єпискоупъ вормєнскыи пришєль к намъ, на нашъ столь... (ССУМ, II, с. 389), з'являється паралельний варіант стіл, у якому спостерігаємо чергування голосних о 3 і у корені слова: сісти на столь (ССУМ, II, с. 389), автори словника спрямовують читачів прослідкувати зв'язок цієї лексеми $з$ дієсловом сєсти. Ознайомлення з тлумаченням цього дієслова приводить нас до висновку про його полісемічність: перше значення вказувало на процес поселення на якійсь території, осідлість; друге, переносне, на позначення високого становища, яке могла займати (посісти) особа (ССУМ, II, с. 340-341). Саме друге значення є найбільш наближеним до лексичного значення столь у попередній історичний мовний період.

Лексема столєиъ також була затребуваною і мала декілька лексичних значень - 'престол' як символ верховної влади: алє вжды хвала милому богу што ваша мл(с)ть зостала оу вашоє мл(с)ти стольцы оу вєликомь кня(з)ствє литовьскомъ; 'престол' як єпископська кафедра: сє я князъ юрія холмъскии снъ данилїа холмъского по

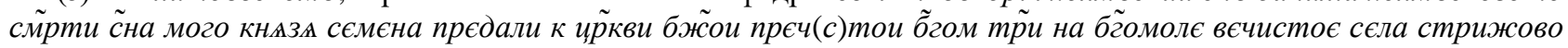
слєпчє... к столу єn(c)піи холмъскоє; словосполучення столєцъ апоустольськии, можливо споріднене 3 латинським sedes apostolica зі значенням 'апостольський престол', 'престол папи римського'; друге значення - місцезнаходження судової інстанції; третє - на позначення чину, тобто посади, службового становища (CСУМ, II, с. 388-389).

Похідне суфіксальне утворення столєчникъ на той час служило для називання члена королівської ради у Польщі (ССУМ, II, с. 389), воно може бути запозиченням або просто калькою зі стп. stołecznik; деривати, утворені суфіксальним способом столникъ, столникь, столник (суфікси -икъ, -икь, -ик) вживалися на позначення державного службовця у Молдавії, який служив при княжому столі під час придворних свят та бенкетів і наглядав за стравами; були назвами боярського чину (ССУМ, ІІ, с. 389). Різна графічна фіксація свідчить про зміни, які відбувалися на той час у мові. Варіант столникоул 'стольник' вживався із тим самим лексичним значенням, тобто означав назву придворного службовця у Молдавії, який служив при княжому столі [ССУМ, II, с. 389]. Прикметник столниковъ (ССУМ, II, с. 389) утворений від столникъ / столникь / столник традиційно суфіксальним способом і вказує на приналежність стольнику. Наявність у мові цього періоду різних форм досліджуваної лексеми може свідчити про активний процес формування лексико-семантичних груп слів української мови, що тісно були пов'язані з давньоукраїнською мовою (Іст. укр. м., с. 279).

У пам'ятках 1-ої половини XVII ст. спорадично подано лексеми столь, престоль, столецъ, які автори словників того часу ставлять не на перше місце, а лише як пояснення до більш вживаних слів. Так у П. Беринди ми дослідили: Прєстоль: столи́ца, кролевскій столо́къ, сбдбнье, маестаг, судище, а чл. столь, столещъ, крбсло (П. Бер., с. 96). У тому самому джерелі синонімами до сьдаліще виступають столе́uъ, кате́дра, з(u)єллинска, а(л)бо си́дьнье (П. Бер., с. 130). На цей час сема столь у більшості випадків вживається для позначення символу влади і лише потім як місце для сидіння. Граматичне оформлення не змінилося. Писемні джерела 2-ої половини XVII ст. зафіксували зміни не лише з боку семантики, а й у плані графічного запису. У документах цього часу ми

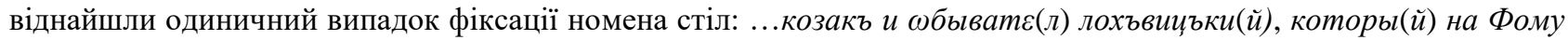

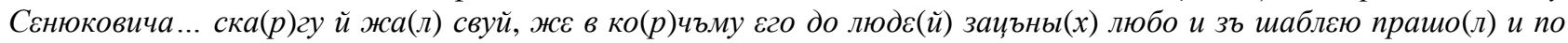

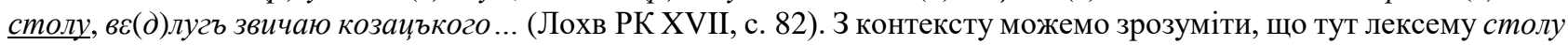
вжито на позначення кухонних меблів, а не з абстрактним значенням, як у попередні мовні періоди. Для номінування одного з видів меблів, що був неодмінним атрибутом української хати і використовувався для приготування та подавння їжі для прийому, автори послуговувалися словом сто (л): anclabra, cmo(л) (Слав. ЛЛ, с. 83); mesa, сєрєдина, сто (л) (Слав. ЛЛ, с. 268); столь, mensa (Слав. та Кор.-Сат. Лекс., с. 512). Для української мови була характерна форма множини: assidela(e), arum, стольл (Слав. ЛЛ, с. 94). Також фіксуємо демінутив, утворений за допомогою типового для української мови суфікса -икъ: abaculus, столикъ (Слав. ЛЛ, с. 61); mensa, mensula, столь, трапеза, столикъ (Слав. ЛЛ, с. 267). У словниках XVII ст. задокументовано сполуки слова столь 3 прикметниками, які вказують на призначення цього виду меблів: abacus, cmo(л) поваровi (Слав. ЛЛ, с. 267); 
Трапеза, столь (Лекс. пр., с. 191). Слово столєцъ лише один раз зафіксовано Л. Зизанієм: столєиъ, полкружникъ, сьдалище (Син. Слав., с. 159); така незначна частота вживання столєцъ може свідчити про втрату його популярності наприкінці XVII ст.: столица, прєстоль, Өронъ (Син. Слав., с. 159).

Словники XIX-XX ст. подають форму столе́uъ зі значенням престоль', наприклад, П. Білецький-Носенко зазначає, що від нього було утворено слово столи́ща (Б.-Н., с. 342). Частковими синонімами до столе́иъ можуть бути маестать (Б.-Н., с. 218) та Єронъ (Б.-Н., с. 416). Більш повно представлена лексема столь // столь іншими авторами: столъ = стіл, має демінутив столикъ, у словосполученні $C$. имъть означає 'столоватся', тобто десь харчуватися (Уманець, IV, с. 85). У словнику М. Уманця та А. Спілки подано паралельну форму до $\mathrm{cmoль} \mathrm{-} \mathrm{cmoль,}$ яка має такеж лексичне значення, відрізняється графічним відтворенням. Російському сто́ликъ відповідає українське столик (наголос в обох мовах на першому складі, відрізняються графікою відтворення); у слові столе́ць наголос переходить на другий склад; косинець зі значенням 'той, що в кутку стоїть ; сирно 'низенький, за котрий сїдають дїлно’; титарня“де продають свічки’ (Уманець, IV, с. 84). Цікавими можуть бути слова столе́шница (можливо, похідне від сто́ликъ) з українським відповідником стольни́ия (Уманець, V, с. 84) та столе́ч(u)ник, а українською перекладається як ска́терть (Уманець, IV, с. 84). Є. Желехівський фіксує слова стіл, стільниия (Жел. II, с. 921), демінутивні форми від стіл - столик, столичок (у коренях слів чергування голосного і в закритому складі з голосним о у відкритому, перший демінутив утворено за допомогою суфікса -ик, другий -ич, -ок). Слово столец̧ь (Жел. II, с. 922), як і в попередніх варіантах, вжито на позначення меблів для сидіння. Автор подає багато похідних від іменника стіл - столове́, столови́й (Жел. II, с. 922), столовни́к / столівни́к (про людину, яка столується (харчується) в конкретному місці). Наголос у похідних падає на останній склад. Слова столонаслідник та столонача́льник утворені способом складання основ, перша основа стол, утворена від столець. Лексичне значення новоутворених слів частково запозичене від лексичного значення столець і означає назви посад, чинів осіб (Жел. II, с. 922). Початкове слово і похідні від нього виражені однією й тією ж частиною мови - іменником.

Б. Грінченко у «Словарі української мови» чітко розмежовує лексичні значення 'стіл' та 'стілець'. Він фіксує: Стіл, стола, столу, м. Столь. Ой ждала ж я, дожидала, столи застилала. Мет. 51. Бував на коні і під конем, на столі і під столом.(Грінч., IV, с. 206). Дериватами від стіл є два суфіксальні утворення демінутивів столик (Грінч., IV, с. 209) та столичок (Грінч., IV, с. 209) (суфікси -ик, -ичок). Вони вказують на функціювання в побуті різних столів за розміром і висотою, що і знайшло відображення на мовному грунті. У цьому періоді продовжує використовуватися лексема стільниця, яка має вже кілька відтінків лексичного значення: 1) Столечница. Канев. Шух. І. 99. 2) Доска, на которой рубять мясо и пр. 3) Верхняя доска высокаго крестьянскаго сундука. Шух. I. 98. (Грінч., IV, с. 206). Слово стольни́ия // стільниця є назвою елементу столу і номінує в українській мові початку XX ст. дошку, на якій сікли м'ясо: Стольни́ця, -ці, ж. = Стільниця. Сікла мясо на стольниці. Левиц. Пов. 128. (Грінч., IV, с. 209). Ще одна назва елементу столу, яку зафіксовано у словнику, $є$ cmóлинє, що служить для називання ножки стола та є частиною столу під столешницею (Грінч., IV, с. 209). Воно утворено суфіксальним способом, як переважна частина дериватів в українській мові. Прикметник столовий (Грінч., IV, с. 209) має безпосереднє відношення до речей, які пов’язані зі столом. Дієслово столувати, тобто ділити стіл (іжу) з кимось: Бсть съ къмъ за однимъ столомъ. Ти зо мною, негарною, ти стіл столуєш, а з чужою, хорошою, ти ніч ночуєш. Грин. III. 344 (Грінч., IV, с. 209), воно утворене за допомогою суфікса -ува від основи -стол-. Досліджувана лексема стол // cmiл, що виражена самостійною частиною мови іменником, послужила основою для творення нових слів переважно суфіксальним способом, які у свою чергу перейшли в прикметники та дієслова. Під час творення окремих слів відбувається характерне для української мови чергування голосного $\mathbf{i}$ в закритому складі з о у відкритому складі.

Сучасна українська літературна мова зберегла лексему стіл як континуант столъ: 1. Вид меблів у вигляді горизонтально укріпленої на ніжках широкої дошки (іноді з ящчиками, тумбочками), на яких розміщують різні предмети. Свиню пусти під стіл, а вона лізе на стіл (Укр. присл., 1955, 168); Сидить батько кінець стола, На руки схилився (Шевч., I, 1963, 25); Старости поклали хліб на столі і почали питати в баби Зіньки, чи віддасть вона Настю за Дениса (Н.-Лев., VI, 1966, 364); Господиня поставила на стіл кухлик молока (Досв., Вибр., 1959, 85); Олександра Олексї̈вна за письмовим столом переписує сторінки великого рукопису (Баш, П'єси, 1958, 7); На операційному столі... лежить хвора дівчина... йй уже дали загальний наркоз і вона тепер міцно спить (Наука, 12, 1961, 32) (СУМ, IX, с. 712). Наведені приклади є свідченням того, що досліджуване слово широко вживається в сучасній українській мові на позначення виду меблів, які є поширеними не лише у побуті, а в інших сферах життя та професійної діяльності людини (письмовий стіл, операџійний). Ще одне значення закріплене у словнику: 2. Такий предмет меблів разом з їжею, що стоїть на ньому. Зевес їй оддавав повагу I посилав од столу брагу (Котл., I, 1952, 217); День народження Платона Кречета. Урочисто прибраний стіл чекає на гостей (Корн., I, 1955, 85); Пообідав листоноша з капітанського столу (Ю. Янов., II, 1958, 205); За святковим столом сиділо чимало уже розігрітих хмелем гостей (Стельмах, I, 1962, 329); * Образно. Буржуазія завжди тягнула $з$ громадського стола найласіші шматки, обкрадаючи народ (Ю. Бедзик, Альма матер, 1964, 96); // перен., розм. Група людей, що їсть за одним столом. Корчма гула від... голосів... Кожний стіл, кожна група живе своӥм життям (Хотк., II, 1966, 185). Подано дещо узагальнене значення, подекуди образне.

Встава́ти (вста́ти, підво́дитися, підве́стися $i m$. $i$.) 3-за сто́лу (стола́) - вставати, закінчивши їсти. Укинула Пріська ложку каші в рот; не пожувавши, ковтнула та й удавилася. 3 тим устала із-за столу (Мирний, III, 1954, 47); Першою підводиться [Настя] з-за столу $і$ з повагою господині несе до припічка ложки, полив'яний полумисок (Стельмах, II, 1962, 106); За оди́н стіл сіда́ти; За одни́м столо́м (при одні́м столі́) [сиді́ти]нехтуючи соціальну нерівність, ставитися як до рівного. - У гласні вибиратимуть $і$ дворяни й мужики... Учора 
мій Омелько в мене кізяки різав, а завтра, може, сидітиме рядом зі мною, за одним столом... Я - гласний $і$ він гласний... (Мирний, I, 1949, 373); За столо́м; При столі́ - під час їі. Людину вільної професії повели до кухні. За столом старий став докладно розповідати про себе (Гончар, III, 1959, 227); [Хуса:] Побудь хвилину тут з нами при столі...[Мелхола:] Я маю їсти з невірними?! (Л. Укр., III, 1952, 153); Збира́ти (зібра́ти) з (зі, зо) стола́ (сто́лу) - збирати посуд і недоїдки. Дарка... почала збирати зо стола (Л. Укр., III, 1952, 669); 3-за сто́лу не вихо́дить хто у кого - регулярно харчується хто-небудь у когось. - В неї оті странники, та ченчики, та богомолки з богомолами $і$ з-за столу не виходять (Хотк., I, 1966, 90); Накрива́ти (накри́ти, застила́ти, застели́ти, опоряджа́ти, опоряди́ти $i m$. $і н$.) стіл; Накрива́ти (накрити, готува́ти, приготува́ти $i m$. $i$.) на стіл - готувати все необхідне для їжі, розставляючи прибори, страви. Для господаря й гостей накрили довгий стіл у світлиці (Н.-Лев., VII, 1966, 53); - Не гайдуки, не маршалки застилають у мене стіл.. Княгині.. тепер служать козакам за столом..! (П. Куліш, Вибр., 1969, 124); [Явдоха:] Я зараз, таточку; хвилиною на стіл накрию (Мирний, V, 1955, 139); Ганна Сильвестрівна почала готувати на стіл (Сенч., Опов., 1959, 9); На столі́ щзо - уже подано їсти що-небудь. От і вечеронька на столі - усі сіли вечеряти (Вовчок, I, 1955, 300); Подава́ти (пода́ти) на стіл подавати якісь страви для їжі. - Домна подає на стіл вечерю (Коцюб., I, 1955, 97); Подаючи на стіл, краєм вуха уважно прислухалась Наталка до розмов (Гончар, II, 1959, 347); Прибира́ти (прибра́ти) зі сто́лу (на столі́) див. прибира́ти; Проси́ти (запроси́ти, кли́кати, покли́кати, кликну́ти $i m$. $i н$.) до сто́лу (за стіл) - запрошувати їсти. -Прошу до столу..., -м'ячиком вертиться перед підполковником Бараболя (Стельмах, II, 1962, 61); Гостей запросили до столу. Частували щеедро й смачно (Тулуб, В степу, 1964, 343); Пили [троянці] на радощах сивуху I ̈̈ли сім'яну макуху, Покіль кликнули їх за стіл (Котл., I, 1952, 72); Саджа́ти (посадови́ти $i$ m. ін.) за стіл починати пригощати. Багатого за стіл саджають, а убогого і так випроводжають (Укр. присл., 1963, 117); 3a стіл посадовила [тітка], вийняла із скрині розшитий калиною рушник, послала молодятам на коліна, припрошуючи покуштувати пирогів (Тют., Вир, 1964, 263); Сіда́ти (сі́сти) за стіл - сідати їсти. - Хіба можна сідати за стіл з немитими руками? - здивувалася Юля (Тют., Вир, 1964, 211); Приказавщи... Тосі - «краще полин їсти, ніж з нелюбом за стіл сісти», - Боженко поспішив до гурту поважних людей (Смолич, Мир., 1958, 62); Сіда́ти (сі́сти) за стіл перегово́рів див. сіда́ти. (СУМ, IX, с. 712). У наведеному уривку іменник стіл найчастіше поєднується з різними дієсловами та прийменниками, у лексичному плані слова з контексту разом із досліджуваною лексемою створюють додаткові відтінки, розширюючи семантику слова.

На сучасному мовному грунті слово стіл може бути узагальненою назвою їжі в цілому: До дня свята дочки вона приготувала великий, добре продуманий стіл (Собко, Матв. затока, 1962, 58); Дедалі багатшим і різноманітнішим стає стіл у кожному домі (Наука, 3, 1972, 50); // Вид їжі, страви; режим харчування. - Мабуть, тебе жінка держить на голодному столі, - говорила далі щебетуха (Н.-Лев., I, 1956, 151); Вегетаріанський стіл; Дієтичний стіл; // Харчування у вигляді сніданків, обідів і вечер. Прохали [знайомі] мене найняти у них 2 хати й стіл (Коцюб., III, 1956, 168) (СУМ, IX, с. 712). Входячи до складу окремих словосполучень, може бути назвою установ або їх відділів, що займаються канцелярською роботою (адресний стіл, стіл знахідок) (CУМ, IX, с. 712); може входити до складу словосполучень, які використовуються у професійно-технічній сфері: Cmiл фpрезерного верстата - це чавунна плита, вздовж якої розташовані T-подібні пази для кріплення на столі деталей (Метод. викл. фрез. спр., 1958, 142); Біля кожного шліфувального круга є поворотний стіл, установлюваний під будь-яким кутом (Технол. різального інстр., 1959, 183) [СУМ, IX, с. 712]; подекуди воно фіксується у спеціальній літературі: Гора, височина $з$ плоскою вершиною та стрімкими схилами. $B$ тих місиях, де на поверхні льоду лежить велике і особливо плескате каміння, утворюється льодовий стовп з каменем зверху, щзо називається льодовиковим столом (Курс заг. геол., 1947, 144) (СУМ, IX, с. 712). В академічному виданні Словника української мови подано ще одне значення: стіл використано як назву князівського престолу у давньокиївський період та розмовний варіант зі значенням символу влади, у поєднанні з дієсловами саджати, посадити - надати князівську владу; сісти на столі - ‘почати правити’ (СУМ, IX, с. 713). У сучасному мовному варіанті відбулися зміни не лише у графічному записі, до цього призвела заміна голосних о на $\mathbf{i}$ у корені слова внаслідок чергування у відкритому та закритому складах після втрати редукованого ь у кінці слова, а й на перший план вийшло лексичне значення слова, пов'язане $з$ побутовою та професійною сферою. Ми дослідили демінутив до стіл - столик, утворений суфіксальним способом (суфікс -ик) (СУМ, IX, с. 726) та демінутивне утворення від столик столичок (суфікс -ичок) (СУМ, IX, с. 727).

Зафіксовано мовознавцями і діалектну назву маленького низенького столика сирно: Маленький низенький столик. Прийшли брати до суддi, вклонились, положили по звичаю на сирно буханиі та й розказали йому про своє діло (Стор., I, 1957, 39); Під хатою стоїть сирно, а на ньому розкішна вечеря (Ю. Янов., II, 1958, 181) (CУМ, IX, с. 199). Етимологія лексеми не прозора. Дослідники роблять припущення, що вона є похідним утворенням від сир $з$ первісним значенням 'дерев'яне блюдо для сиру' (ЕСУМ, V, с. 242). У пам'ятках та словниках XII-XX ст. ми не віднайшли цієї лексеми. У словнику Білецького-Носенка записана сема сирь 'творогъ' (Б.-Н., с. 327), прикметник сирний зі значенням 'твороженый '(Б.-Н., с. 327), іменник си́рникъ 'лепешка, спеченная изъ сиру' (Б.-Н., с. 327), але вони не мають відношення до назви меблів. С. Желехівський подає слово си́рно для називання у німецькій мові саме невеликого столика (Жел., ІІ, с. 866), у Б. Грінченка: Сирно, -на, с. Маленькій, низенькій столикъ, вокругъ котораго сидять на земль (О. 1861. ХІ. Кух. 26). Прийшли брати до судді, вклонились, положили по звичаю на сирно буханџі (Стор. I. 33. С. (Грінч., IV, с. 122)).

Сучасні назви різновидів столу бувають такими: однотумбовий (СУМ, V, с. 640), двотумбовий (СУМ, II, c. 226), бо вони мають одну чи дві тумби. Це наводить нас на думку, що змінився не лише графічний запис слова cmiл, додалися прикметники, які уточнюють цю назву, бо змінилися і форми стола та розширилося його 
функційне призначення. Сучасні словники містять назву різновиду письмового столу бюро (СУМ, I, с. 269), такі письмові столи мали висувну кришку і шухляди для паперів та конторку. Слово бюро є багатозначним і згадане тлумачення не єдине, інші визначення не мають нічого спільного з назвою згаданого виду меблів. Бюркозменшено-пестливе від бюро (зі значенням назви меблів) (СУМ, I, с. 269). Це запозичення з французької мови; французьке bureau зі значенням письмовий стіл, канцелярія, контора в свою чергу походить від bure, що означає 'скатерть, груба вовняна тканина; присутнє у російській, білоруській, болгарській - бюро, польській - biuro, чеській - byro', bureau (ЕСУМ, I с. 315). Російські мовні джерела містять слово бюро: БЮРО ср. несклон. род комода, поставиа на ножках, с выдвижною столешницею и ящиками, для письменных дел; письмовник, письменник, грамотейка.| Во Франциии, правительственное место. Бюрократия ж. управление, где господствует чиноначалие; степенная подчиненность; зависимость каждого служебного лица от высшего и бумажное многописание при этом; многоначалие и многописание; -тичный, -ческий, к сему относящийся. Бюрократ м. -тка ж. защитник этого образа правления. (Даль, с. 85). Перекладний Українсько-російський словник містить лексему стіл, що відповідає російському стол і має такі ж тлумачення, та похідні від неї: укр. столик, столичок рос. столик (УРС, V, с. 515).

Прикметник столовий утворений від першого значення іменника стіл і тому може входити до складу словосполучень типу столова дошка, столова сіль, картопля, буряк, гарбузи, столове вино (види продуктів харчування); значно рідше столовий гарнітур, столова лампа; у спеціальній сфері може бути назвою плоскої вершини і стрімких, урвистих схилів (СУМ, IX, с. 727).

Стільниця як назва елементу (частини) столу, що означає назву верхньої дошки, кришки столу або є назвою дошки, на якій місять тісто чи січуть м'ясо, продовжує використовуватися у мові. Ще вона означає назву верхньої дошки високої селянської скрині, яка була не прикріплена до скрині (СУМ, IX, с. 715). На сьогодні скрині як вид хатніх меблів не є затребуваними, тому, на нашу думку, це лексичне значення втратило свою актуальність. Стільничка є демінутивним утворенням від стільниия: СТІЛЬНИ́ЧКА, и, ж. Зменш.-пестл. до стільни́ця. Одчинила я свою скриню та й поклала зверху стільничку з котлетами (Н.-Лев., III, 1956, 263) (СУМ,IX, с. 715). Українському стільниця відповідає російське столешница (УРС, V, с. 510), але український демінутив стільничка не має російського відповідника.

Білоруська мова містить лексему стальніца, що українською означає назву верхньої дошки, кришки стола (БУС, с. 572).

У словнику бойківських діалектів фіксується відповідник до стіл - сто́лойко, дієслівне утворення столуватися зі значенням 'харчуватися', одним зі значень слова столиць, фонетичний варіант столи́е ’ $€$ 'столик, який переноситься з місця на місце' (Онишк., II, с. 255). Для називання верхньої частини столу у діалектах збереглося слово сто́лина, що служить для називання споду стола у формі скрині без віка, на яку кладуть ”стіл”, тобто дошку, столешницю (Онишк., II, с. 254), збереглася форма множини сто́лини зі значенням 'дошки, що з'єднують "коники”, тобто ніжки стола', 'дошки навкруг ніжок стола, які утворюють скриню'; 'подовжні стінки стола' (поперечні дошки разом з ніжками стола - коники) (Онишк., II, с. 254-255). У словнику подано ще варіанти підстелина, підсто́лина (Онишк., II, с. 71), сто́линя. Вони означають те саме, що й сто́лина.

Висновки. Лексема столь / столь, має деривати - іменник стольникъ, прикметник стольничии; прикметник стольний є дериватом від престол; варіанти столєцъ і похідне столєчникъ та деривати від нього столникъ / столникь / столник мають праслов'янське коріння, були зафіксовані у текстах пам'яток та словниках на всіх етапах історичного розвитку української мови. За цей час вони зазнали змін на графічному та фонетичному рівнях, дещо змінювалися відтінки лексичних значень у слові стіл (у сучасному трактуванні воно означає назву не лише конкретного предмета, а може виступати узагальненою назвою їжі в цілому). Назва елементу стола стольниця / стільниця подано в СУМ, але для широкого вжитку воно не є актуальним. Ще одна назва елементу стола столинє не збереглася у сучасній українській літературній мові.

Слід і надалі продовжувати дослідження лексико-семантичних груп української побутової лексики. Досить значна кількість лексичних одиниць, що служать для називання видів посуду як хатнього начиння та меблів $\epsilon$ широко затребуваними на сучасному мовному рівні. Результати їх вивчення повинні стати підгрунтям для подальших лінгвістичних досліджень з метою систематизації.

\section{References}

1. Buriachok, Andrii. Nazvy sporidnenosti i svoyatsva v ukrainskyi movi. (Names of kinship and virility in the Ukrainian language). - Kyiv: Vydavnytstvo AN URSR, 1961. Print.

2. Horobets, Vasyl. Leksyka istorychno-memuarnoi prozy pershoi polovyny XVIII st.: na materiali ukrainskyh diariushiv. (The vocabulary of the historic-memoir prose of the first half of the XVIII century: On the material of Ukrainian diaries). - Kyiv: Naukova dumka, 1979. Print.

3. Istoriya ukrayins'koyi movy: Leksyka i frazeolohiya / redkol.: V. M. Rusanivs'kyy, V. L. Karpova, V. V. Nimchuk, I. L. Chepiha. Kyiv: Nauk. Dumka, 1983. 744 s.

4. Muromtseva, Olha. Rozvytok leksyky ukrainskoi literaturnoi movy u drugiy polovyni XIX - na pochatku XX st. (Development of the vocabulary of the Ukrainian literary language in the second half of the XIX - early XX centuries). Kharkiv: Vyscha shkola, 1985. Print.

5. Najenko, Halina. "Astronomichna terminolohiia u " Lexykoni Slovenoroskomu” Pamvy Beryndy" ("Astronomical terminology in the "Lexicon of Slovenian" Pamba Berynda). Visnuk Kuivskoho universutetu (Bulletin of the Kiev University). 6 (1998): 50-53. Print. 
6. Pryskoka, Oleh. "Slidy avtorskoi pratsi v arkhitekturniy leksytsi davnikh ukrainskykh pysemnykh pamyatok" ("Traces of the author's work in the architectural vocabulary of ancient Ukrainian written monuments "). Kyivska starovyna (Kiev Starovyna). 4 (2004): 25-27. Print.

\section{List of Sources}

1. Б.-H. (B.-N.) - Biletsky-Nosenko P. Slovnik Ukrayinskoi movy (Dictionary of the Ukrainian language) / pidgot. do vyd. V.V. Nimchuk. Kiev: Naukova Dumka, 1966. 421 p. Print.

2. (BUS) - Pivtorak G., Skopenko O. Bilorusko-ukrainskyi slovnyk (Belarussian-Ukrainian Dictionary). Kiev: Vydavnytsvo «Dovira», 2006. Print.

3. Грінч. (Grinch) - Slovnyk Ukrayinskoi movy (Dictionary of the Ukrainian language) v $4 \mathrm{t}$. / za red. B. D. Grinchenko. Kiev: Lexykon, 1996. Print.

4. Жел. (Zhel.) - Zhelehivsky Ye. Malorus'ko-nimetskyy slovnyk: v 2 t. (Malorussian-German Dictionary) / uklaly: Eugene Zhelehivsky and Sofron Nedilsky. Lviv: drukarnia tovarystva im. Shevchenko, 1886. T. 1. 592-1122 p. Print.

5. ЕСУМ (ESUM) - Etymologichnyi Slovnyk ukrainskoyi movy: v 7 t. (An Etymological Dictionary of the Ukrainian Language: in 7 volumes) /redkol: O. S. Melnichuk ta in. Kiev: Naukova Dumka, 1989. Chast. 3. 560 pp.; Kiev: Naukova Dumka, 1983. T. 5. 704 p.

6. ЛК (LK) - Kyivskyi litopys // Ipatyevskaya letopis (Chronicle of Kyiv // Hypatian Codex.) - [2 $2^{\text {nd }}$ edition]. StP., 1908. - (Poln. sobr. rus. letopisey). - Vol. 2. - P. 715-938. Print.

7. ЛохвPK XVII (LokhvRK XVII) - Lokhvytska ratushna knyga drugoi polovyny XVII st.: zbirvyk aktovykh dokumntiv (Lochvytsa City Hall Book of the second half of XVII century: the collection of acts) // Editorial board: O. M. Mashtabei, V. G. Samiylenko, B. A. Sharpylo. - K.: Naukova dumka, 1986. Print.

8. Онишк. (Onishk) - Onishkevich M. Y. Slovonik Boykivskih govirok: U 2 h. (Dictionary of Boiko dialects) / Redkol. G. M. Gnatyuk, P. Yu. Gritsenko, I. G. Matviyas, M. M. Peshchak, Z. F. Franko. Kiev: Naukova Dumka, 1984. Chast. 2: O-Ya. 623 p. Print.

9. ПВЛ, ЛЛ (PVL, LL) - Povest vremennykh let // Lavrentyevskaya letopis (Tale of Bygone Years // Laurentian Chronicle.) - 2nd edition. - Leningrad: Izdatelstvo AN USSR, 1926-1927. - 286 p. Print.

10. Син. Слав. (Syn. Slav.) - Sinonima Slavenorosskaya: "Lexis" Lawrence Zizania. "Sinonima Slavenorosskaya" / pidgot. text and pam'yatok i vstup st. V.V. Nimchuk. Kiev: Naukova Dumka, 1964. P. 91-172. Print.

11. Слав. ЛЛ (Slav. LL) - Slavynetskyi Y. (Leksykon Latynskyi // Slavynetskyi Y. Leksikon Latynskyi Ye. Slavynetskogo. Leksykon slaveno-latynskyi Y. Slavynetskogo ta A. Koretskogo-Satanovskogo (Latin Glossary // Slavynetskyi Y. Latin Glossary by Slavynetskyi Y. Latin-Slavic Dictionary. Slavynetskyi Y. and Koretskyi-Satanovskyi / [Ed. by V. V. Nimchuk]. Kiev: Naukova dumka, 1973. - P. 59-420. Print.

12. Слав. та Кор.-Сат. Лекс. (Slav. ta Kor.-Sat. Leks) - Slavynetskyi Y. (Leksykon Latynskyi // Slavynetskyi Y. Leksikon Latynskyi Ye. Slavynetskogo. Leksykon slaveno-latynskyi Ye. Slavynetskogo ta A. Koretskogo-Satanovskogo (Latin Glossary // Slavynetskyi Y. Latin Glossary by Slavynetskyi Y. Latin-Slavic Dictionary Slavynetskyi Y. and Koretskyi-Satanovskyi / [Ed. by V. V. Nimchuk]. K.: Naukova dumka, 1973. - P. 423-541. Print.

13. Срезн. (Strezn.) - Sreznevsky I. I. Materialy dlia slovaria drevnerusskogo yazyka (The Materials for a Dictionary of the Old Russian Language). Saint-Petersburg. 1893. T. 1: A-K. 272. Print.

14. SSMU (CCYM) - Slovnyk staroukrainskoi movy XIV-XV st. (Dictionary of the Old Ukrainian Language XIV-XV ст): u 2 t. Kyiv: Naukova Dumka, 1977. T. 1. 630 p. Print.

15. СУМ (SUM) - Slovnyk ukrainskoi movy: 11 t. (Dictionary of the Ukrainian Language: in 11 volumes) Kyiv: Naukova Dumka, 1970-1980. T. 1-11. Print.

16. Уманець (Umanets) - Umanets M., Spilka A. Slovar rosiisko-ukrainskyi. (Russian-Ukrainian Dictionary). Lviv, 1893-1894. - Vol. 1-2. Print.

17. УPC (URS) - rosiiskyi slovnyk (Russian-Ukrainian Dictionary): [in 6 vol.] / AN URSR, Institut movoznavstva im. O. O. Potebnia; chief editor I. M. Kyrychenko; editorial board: T. V. Zaitseva, M. T. Rylskyi. - Kyiv: Vydavnytsvo AN URSR, 1953-1963. Print.

18. Ф. (F.) - Fasmer M. Etumolohichui slovar russkoho yazyka (Etymological dictionary of the Russian language). Moskva: Progress, 1964-1973. Volume 1-4. Print.

\section{HISTORY OF THE WORD TABLE (CTIJ) AS REPRESENTATION OF THE COMMON SLAVIC NAME OF FURNITURE \\ Liana Naumenko}

Department of Journalism, Ukrainian Literature and Culture, University of the State Fiscal Servise of Ukraine, Irpin, Ukraine

\section{Abstract}

Background: Everyday vocabulary can be of particular interest for researchers. Until now, this group of thematic vocabulary is not sufficiently studied in the historical and linguistic aspects. In modern linguistics, specific lexical, semantic and thematic groups of words are widely studied.

Purpose: The purpose of the study is to consider and analyze the lexical items that are part of the lexical and semantic group of names for the table and its parts throughout their functioning in the Ukrainian language (XII-XX centuries).

Results: In this study, we examined the lexical and semantic group of names for table and its parts, and observed the changes in the lexical meaning of the words under consideration. We paid attention to ways of word-forming of 
derivatives and diminutive forms from nomens. During the analysis of the investigated material, the etymology of the lexical item стіл (table) was considered via various authors' interpretations. We have come to the conclusion that the lexical item столь / столь (table / table) has the derivative forms: the noun стольникъ, the adjective стольничии; the adjective стольний is derivative of престол (throne); the forms столєиъ and the derivative form столєчникъ with its derivative forms столникъ / столникь / столник have Proto-Slavic roots and were recorded in the literary works and dictionaries at all stages of the Ukrainian language historical development. During this time they have undergone changes on the graphic and phonetic levels, and some changes in the nuances of lexical meanings in the word cmir (table) (in the modern interpretation, it is not only the name of a particular subject, it may also be a name for the food in general). The noun стольниия / стільниия (tabletop) is the name of the part of the table. It is provided in the dictionary of modern Ukrainian language, but it is not relevant for general use. Another name of the table part, столинє, is not preserved in modern Ukrainian literary language.

Discussion: The study of lexical and semantic groups of Ukrainian vocabulary should be continued. The results of this study should be the basis for further linguistic research and systematization.

Key words: historical dialectology of the Ukrainian language, historical lexicology and word formation of the Ukrainian language, lexical meaning, polysemic, diminutive.

Vitae

Liana Naumenko is senior lecturer at Department of Journalism, of Ukrainian Literature and Culture, University of the State Fiscal Servise of Ukraine, Irpin, Ukraine. Spheres of scientific interests: history of the Ukrainian language, lexicology, topical issues of the culture of communication.

Correspondence: naumenko.liana@gmail.com

Надійшла до редакції 25 березня 2019 року.

DOI $10.31558 / 1815-3070.2019 .37 .3$

УДК 811.161.2'374.26

\title{
ВИТОКИ Й СТАНОВЛЕННЯ УКРАЇНСЬКОЇ ТЕРМІНОГРАФІЇ
}

Тетяна Петрова

\author{
Укладання словника - підсумок термінографічної роботи \\ щзодо опису й кодифікування певної термінологї̈ як системи
}

Віднайдено перші “плоди” украӥнської термінографії, відстежено ї̈ становлення як науки з методологічною основою, проаналізовано динаміку розвитку засад термінотворення й принципів побудови термінологічних словників, окреслено проблеми сучасної начіональної термінографї, розглянуто типологійну класифікацію спеціальних словників і визначено ї “білі плями”, зокрема вказано на відсутність лексикону нового типу - термінологічного словника комбінованого типу.

Ключові слова: термінографія, термінологічний словник, принципи побудови термінологічних словників, типологійна класифікація спеціальних словників, термінологічний словник комбінованого типу.

Створення спеціальних словників має свою історію та специфіку. Лексикографія - найдавніша галузь людства, особливе місце в ній посідає термінографія. Як стверджують дослідники, українська термінологічна лексикографія має понад двохсотлітню історію (Symonenko “Osnovni napryamky rozvytku”). Дослідженню термінографії присвячені праці зарубіжних лінгвістів: С. Гриньова, 3. Комарової, В. Щербіна та ін. В українському мовознавстві на сучасному етапі теоретичні засади термінографії розробляють В. Дубічинський, О. Іванова, М. Комова, І. Кочан, Л. Симоненко, Л. Туровська та ін. Незважаючи на те, що відстеження початків і вивчення особливостей становлення української термінографії мовознавці здійснювали неодноразово, усе ж таки ці питання залишаються актуальними й сьогодні.

Мета дослідження - відстежити витоки національної термінографії, показати ії досягнення, напрацювання й проблеми; завдання - віднайти перші “плоди” української термінографії, відстежити динаміку розвитку засад термінотворення й принципів побудови фахових словників, окреслити проблеми сучасної національної термінографії, розглянути типологійну класифікацію спеціальних словників і визначити іiі “білі плями”.

Найменування термінографія, термінологічна лексикографія, а також спеціальна лексикографія дослідники вживають як абсолютні синоніми (Komova, “Ukrayins'ka terminohrafiya”). Поняття “термінографія” почали використовувати в 70-х рр. ХХ ст. Ураховуючи вироблені на сьогодні концептуальні лексикографічні парадигми, В. Іващенко зауважує: “Слово термінографія має три значення, причому перше і третє варіюються у семантичних відтінках, а саме: 1) розділ лексикографії як наукова дисципліна про складання спеціальних словників; // теорія і практика укладання термінологічних словників; 2) вид практичної діяльності, пов'язаний зі збиранням, систематизацією, фіксацією та описуванням термінологічного матеріалу; 3) сукупність термінологічних довідкових видань як окремої галузі знань, так і мови загалом; // сукупність теоретичних досліджень у цій галузі” (Ivashchenko 142).

(С) Петрова Т., 2019 